\title{
Biodiversity of soil algae in the farmlands of mid-Taiwan
}

\author{
Ching-Su Lin ${ }^{1}$, Tsuan-Ling Chou ${ }^{1,2}$ and Jiunn-Tzong $\mathrm{Wu}^{1,2^{*}}$
}

\begin{abstract}
Background: Very little information is available about soil algae in Taiwan. In this study, we investigated for the first time the soil algae inhabiting five types of farmland in mid-Taiwan: rice paddies, vegetable farms, tea plantations, sugar cane farms, and orchards.

Results: Sixty-four taxa belonging to 33 genera of cyanobacteria, diatoms, green algae, and euglenoids were identified on the basis of fine structures observed under optical and electron microscopes and rDNA sequencing. The majority of the isolates were of the genera Oscillatoria, Navicula, Nitzschia, and Pinnularia. Five species were reported for the first time in Taiwan, namely Microcoleus paludosus, M. subtorulosus, Navicula subminuscula, Nitzschia levidensis, and Ni. pusilla.

Conclusions: The distribution and diversity of these species was shown to be strongly dependent on habitat, with the highest diversity of green algae in the orchards, a fairly high diversity of diatoms and cyanobacteria in the rice paddies, and a relatively low diversity in the tea plantations and sugar cane farms. The humidity and acidity were the most important environmental factors influencing the diversity of soil algae in these farmlands.
\end{abstract}

Keywords: Biodiversity; Farmland; Soil algae; Soil cyanobacteria; Subtropical Taiwan

\section{Background}

Soil is the most important non-aqueous habitat for algae and cyanobacteria (blue-green algae) (Zenova et al., 1995). Due to their high capacity for morphological and physiological adaptations to different environments, both algae and cyanobacteria often act as pioneer microorganisms in terrestrial ecosystems (Metting, 1981; Hoffmann, 1989). In farmlands, soil algae and cyanobacteria play an important role because they both have tremendous potential to serve as sources of nitrogen and carbon for other organisms. Soil fertility is generally improved by the organic matter produced by these organisms (Mishra and Pabbi, 2004). Soil algae excrete growth-promoting substances such as hormones, vitamins, amino acids, and organic acids that affect other organisms in many ways (Roger and Reynaud, 1982; Wilson, 2006). The presence of soil algae also stabilizes the soil surface and thus reduces erosion (Evans and

\footnotetext{
* Correspondence: jtwu@gate.sinica.edu.tw

${ }^{1}$ Institute of Ecology and Evolutionary Biology, National Taiwan University, 1, Roosevelt Road Section 4, Taipei 106, Taiwan

${ }^{2}$ Biodiversity Research Center, Academia Sinica, 128, Academia Road Section 2, Nankang, Taipei 115, Taiwan
}

Johansen, 1999; Hu et al., 2004). The polysaccharides produced by some soil algae increase soil porosity, aggregation, and water-holding capacity (Roger and Reynaud, 1982; Choudhary et al., 2007). Soil algae are also ameliorators in the reclamation of saline and metals, thereby improving soil quality (Rai et al., 1998; Whitton and Potts, 2000).

Several studies have noted that the inoculation of farm soils with algae increases grain yields by $15-25 \%$ (Yanni et al., 1992; Gurung and Prasad, 2005; Song et al., 2005). Cyanobacteria are the preferred bio-fertilizer, because they perform two key biological processes: oxygenic photosynthesis and nitrogen fixation (Relwani, 1963; Ernst et al., 1992). The commonly used nitrogen-fixing species are of genera Anabaena, Calothrix, Nostoc, Schizothrix, and Scytonema (Kannaiyan, 1990; Rai et al., 2000).

The identification of unicellular or crustose algae is problematic, especially when only limited sample material is available (Burja et al., 2001; Presting, 2006). In recent years, molecular tools have improved the precision of species identification and allowed eco-physiological and biochemical approaches to biodiversity assessment (Srivastava et al., 2007). Although some soil algae have

\section{Springer}


been studied in certain localities in various regions across the world, information about the diversity and ecological characteristics of soil algae in Taiwan is very limited. In this study, we conducted a survey of soil algal diversity in different types of farmland in mid-Taiwan using both morphological observations with optical and scanning electron microscopes and molecular data from rDNA sequences.

\section{Methods}

\section{Sampling and morphological observations}

Soil samples from different types of farmland in the counties of Miaoli, Taichung, Changhua and Nantou from mid-Taiwan, including rice (Oryza sativa Linn.) paddies, vegetable farms (mainly growing white cabbage, Brassica oleracea var. capitata L.), tea (Camellia sinensis L.), and sugar cane (Saccharum officinarum L.) plantations, and orchard farms (mainly growing orange Citrus sinensis L., and tangerine C. reticulata Blanco.) were collected seasonally over the time from May 2010 to May 2011, namely May, August, and November of 2010 and February, May of 2011, by removing the surface debris from five to seven randomly selected sites and scraping about $500 \mathrm{~g}$ of soil from the upper centimeter of soil at each site. After thorough mixing and sieving (through a 1.0-mm mesh), the soil samples were stored in polythene bags and brought to the laboratory. About $10 \mathrm{~g}$ of each sample was placed in a flask and diluted 100-fold with distilled water. After shaking for $1 \mathrm{~h}$, the soil suspensions were fixed with formaldehyde solution (at a final concentration of 1\%). A part of each fixed soil suspension was boiled in $10 \% \mathrm{H}_{2} \mathrm{O}_{2}$ solution to remove any organic material and was repeatedly rinsed with distilled water to obtain cleaned diatom frustules (Fujita and Ohtsuka, 2005). Algae were identified by direct examination using an AxioStar microscope (Zeiss, Germany) equipped with transmitted light, phase contrast, and differential interference contrast (DIC, Nomarski) illumination. The findings were photo-documented using a ProgRes digital microscope camera (Jena, Germany).

\section{Scanning electron microscope (SEM)}

To observe the fine structures of the diatom frustules, about $1 \mathrm{~g}$ of each sample was treated with sulfuric/ acetic (1: 9) acid solution, as described by Chen and Wu (1999). The samples were then dehydrated through an alcohol series and dried with a critical point dryer (Hitachi HCP-2). The dried diatoms were mounted on an aluminum stub and coated with gold by a sputter coater (Edwards S150A) and viewed on an FEI Quanta 200 scanning electron microscope (SEM).

The determination and nomenclature of the organisms were carried out with reference to the relevant texts (Desikachary, 1959; Prescott, 1962; Patrick and Reimer,
1975; Anagnostidis and Komárek, 1990; Komárek and Anagnostidis, 1999, 2005; John et al., 2002; Kobayasi et al., 2006).

\section{Isolation, culture, and DNA sequencing}

A total of $0.1 \mathrm{~mL}$ of the soil suspensions without formaldehyde solution was inoculated in triplicate on both liquid and solid (1.5\% agar) mediums of BG11 (Stanier et al., 1971) and NC (Kuhl, 1962), respectively. The inoculations were kept in a greenhouse under a 12:12 light-dark (LD) cycle and illuminated with cool white fluorescent light at $40 \mu \mathrm{E} \mathrm{m} \mathrm{m}^{-2} \mathrm{~s}^{-1}$ and $25^{\circ} \mathrm{C}$. The isolates were microscopically observed and prepared for subsequent DNA isolation and further analysis.

The DNA of the soil algae was extracted using the phenol-chloroform protocol (Saunders, 1993). Amplification was carried out using the PCR primer pair $359 \mathrm{~F}$ (5' GAA TYT TCC GCA ATG GGC 3') and CYA781R (an equimolar mixture of CYA781R-a (5'GAC TAC TGG GGT ATC TAA TCC CAT T3') and CYA781R-b (5' GAC TAC AGG GGT ATC TAA TCC CTT T 3')) of $16 \mathrm{~S}$ rDNA for the cyanobacteria (Nübel et al., 1997); primer pair P73F (5'AAT CAG TTA TAG TTT ATT TGR TGG TAC C3') and p47R (5'TCT CAG GCT CCC TCT CCG GA3') of $18 \mathrm{~S}$ rDNA for the eukaryotic algae (Bérard et al., 2005); or primer pair p23SrV_f1 (5' GGA CAG AAA GAC CCT ATG AA 3') and p23SrV_r1 (5' TCA GCC TGT TAT CCC TAG AG 3') of $23 \mathrm{~S}$ rRNA for both (Sherwood and Presting, 2007). The PCR amplification was performed in an Eppendorf Mastercycler gradient $\mathrm{S}$ thermal cycler (Eppendorf, Hamburg, Germany) using a $50 \mu \mathrm{L}$ solution mixture consisting of $5.0 \mu \mathrm{L}$ of 10X PCR buffer, $4.0 \mu \mathrm{L}$ of $2.0 \mathrm{mM} \mathrm{MgCl}_{2}$ (Promega), $3.0 \mu \mathrm{L}$ of $1.0 \%$ BSA solution, $2.0 \mu \mathrm{L}$ of each primer (0.4 mM), $2.0 \mu \mathrm{L}(20 \mathrm{mM})$ of each dNTP, $0.2 \mu \mathrm{L}$ of Taq polymerase (Promega), $26.0 \mu \mathrm{L}$ of $\mathrm{H}_{2} \mathrm{O}$ (bidist.), and $1.0 \mu \mathrm{L}$ of genomic DNA. The cycling conditions consisted of heating at $94^{\circ} \mathrm{C}$ for 5 minutes, followed by 35 cycles of $94^{\circ} \mathrm{C}$ for $1 \mathrm{~min}, 60^{\circ} \mathrm{C}$ for $1 \mathrm{~min}$ for the $16 \mathrm{~S}$ and $18 \mathrm{~S}$ rDNA primers $\left(55^{\circ} \mathrm{C}\right.$ for the $23 \mathrm{~S}$ primers $), 72^{\circ} \mathrm{C}$ for $1 \mathrm{~min}$, and a final extension time of $72^{\circ} \mathrm{C}$ for 10 minutes. The PCR products were visualized on $1 \%$ agarose gel stained with ethidium bromide $(\mathrm{EtBr})$, further purified using a Qiagen PCR purification kit (Stratagene, CA, USA).

The PCR products were sequenced commercially in both directions. The forward and reverse-complementary of the reverse sequences obtained were aligned to check the quality of the sequences. Ambiguous bases were checked and altered using the BioEdit program. Sequences were compared to known samples and environmental samples using the BLAST search tool on the National Center for Biotechnology Information (NCBI) website (http://www.ncbi.nlm.nih.gov). 


\section{Physicochemical properties of soil}

Soil samples were soaked in deionized water $(1: 5 \mathrm{v} / \mathrm{v})$ to prepare a soil solution for the measurements of $\mathrm{pH}$ and electrical conductivity (Thermo Orion 720A, USA) (Jackson, 1962). For determination of soil humidity, soil samples were dried at $105^{\circ} \mathrm{C}$ for $48 \mathrm{~h}$ and measured for weight loss. The content of organic matter in soils was determined by measuring the loss-on ignition (Ball, 1964). In addition, total $\mathrm{C}$ and $\mathrm{N}$ were analyzed using an elemental analyzer (Heraeus Vario III-NCH, Germany). Chlorophyll-a (Chl- $a$ ) in soil samples was extracted with $90 \%$ acetone and quantified according to the methods described by Tsujimura et al. (2000).

\section{Statistical analysis}

The indices of soil algal communities were estimated: Shannon species diversity index $(\mathrm{H})$ by $\mathrm{H}=-\Sigma\left(p_{i}\right)\left(\log _{2} p_{i}\right)$, where $p_{i}$ is the proportion of the individual species (Shannon and Weaver, 1949); evenness index (E) by $\mathrm{E}=\mathrm{H} / \mathrm{H}_{\max }$, where $\mathrm{H}_{\max }=\log _{2}(\mathrm{~S})$ and $\mathrm{S}$ the total number of species (Margalef, 1958); Simpson's diversity index (D) by $\mathrm{D}=1-\Sigma\left(p_{i}\right)^{2}$ (Simpson, 1949). These indices were calculated, using the EstimateS 8.2 software (Colwell, 2009). The data were also subjected to Pearson correlation analysis using SYSTAT (version 12, Systat Software Inc., Richmond CA, USA). Differences were considered to be significant at $p<0.05$ level.

\section{Results}

\section{Physicochemical properties of soil}

The studied farmlands, with exception in rice paddy, are acidified with $\mathrm{pH}$ ranging between 4.09 and 6.48 (Table 1). The lowest $\mathrm{pH}$ was measured for tea garden, while the highest for rice paddy. The acidity exhibited a close correlation with the soil content of total nitrogen (Table 2), indicating a possible result of fertilizer application in these lands.

The highest density of soil algae (displayed as Chl- $a$ content) was measured for rice paddies, where the contents of electrical conductivity (EC), humidity (HU), organic matter (OM), total carbon (TC) and total nitrogen
Table 2 Pearson correlation coefficients between physicochemical variables measured at various farmlands in mid Taiwan $(n=55)$

\begin{tabular}{llllllll}
\hline & Chl- $\boldsymbol{a}$ & pH & EC & HU & TC & TN & OM \\
\hline $\mathrm{pH}$ & $-0.64^{*}$ & & & & & & \\
EC & 0.49 & $-0.68^{* *}$ & & & & & \\
HU & $0.73^{* * *}$ & -0.08 & 0.42 & & & & \\
TC & $0.71^{* *}$ & -0.39 & $0.77^{* *}$ & $0.58^{*}$ & & & \\
TN & $0.63^{*}$ & $-0.82^{* * *}$ & $0.67^{* *}$ & -0.11 & $0.73^{* *}$ & & \\
OM & $0.52^{*}$ & -0.43 & 0.22 & $0.72^{*}$ & $0.83^{* * *}$ & $0.69^{*}$ & \\
CC & 0.41 & -0.12 & 0.24 & 0.51 & 0.25 & -0.11 & 0.39 \\
\hline
\end{tabular}

CC: canopy coverage; Chl- $a$ : chlorophyll- $a$; EC: electrical conductivity; $\mathrm{HU}$ : humidity; OM: organic matter; TC: total carbon; TN: total nitrogen. The significance level: ${ }^{* * *}, p<0.001 ;{ }^{* *}, p<0.01 ;{ }^{*}, p<0.05$.

(TN) were also high (Table 1 ). The density of soil algae was correlated positively with $\mathrm{HU}, \mathrm{TC}, \mathrm{TN}$, and $\mathrm{OM}$ $(p<0.05)$ (Table 2). A negative correlation coefficient existed between Chl- $a$ content and $\mathrm{pH}$ values $(p<0.05)$, suggesting that less soil algae were revealed in acidic lands.

\section{Biodiversity in different types of farmland}

Based on the morphology observed under the LM and SEM, a total of 64 species were identified in the studied farmlands (Table 3). They belonged to diatoms, cyanobacteria, green algae, and euglenoids in 4 classes and 33 genera. The highest diversity of species was found for the diatoms (27 species), which were mostly of the genera Navicula, Nitzschia, and Pinnularia, followed by cyanobacteria (22 species), and then green algae (13 species) (Tables 3 and 4). The highest number of taxa was found for the genus Oscillatoria (cyanobacteria). Five species are reported for the first time in Taiwan, including the cyanobacteria M. paludosus and M. subtorulosus and the diatoms Na. subminuscula, Ni. levidensis, and Ni. pusilla (Figures 1, 2, 3 and 4).

The soil algae in the rice paddies and vegetable farms were characterized by the dominance of cyanobacteria, a paucity of green algae, and a diverse flora of diatoms

Table 1 Physicochemical properties of soils in various farmlands in mid Taiwan

\begin{tabular}{|c|c|c|c|c|c|}
\hline Parameter & Rice paddy & Vegetable farm & Sugarcane farm & Tea garden & Orchard \\
\hline $\mathrm{pH}\left(\right.$ in $\left.\mathrm{H}_{2} \mathrm{O}\right)$ & $7.73 \pm 0.88$ & $6.48 \pm 0.18$ & $6.14 \pm 0.83$ & $4.09 \pm 0.61$ & $5.61 \pm 0.32$ \\
\hline $\mathrm{EC}(\mu \mathrm{S} / \mathrm{cm})$ & $232 \pm 65$ & $175 \pm 36$ & $73 \pm 16$ & $114 \pm 28$ & $146 \pm 29$ \\
\hline HU (\%) & $13.26 \pm 3.85$ & $7.24 \pm 2.83$ & $2.68 \pm 1.66$ & $4.82 \pm 2.99$ & $7.94 \pm 3.69$ \\
\hline Chl- $a(\mu \mathrm{g} / \mathrm{L})$ & $4.69 \pm 1.20$ & $3.14 \pm 0.86$ & $0.88 \pm 0.28$ & $1.81 \pm 0.57$ & $2.93 \pm 1.01$ \\
\hline OM (\%) & $3.36 \pm 0.36$ & $2.84 \pm 0.27$ & $1.53 \pm 0.14$ & $2.04 \pm 0.09$ & $2.37 \pm 0.24$ \\
\hline TC (\%) & $2.91 \pm 0.24$ & $2.77 \pm 0.20$ & $1.88 \pm 0.13$ & $2.18 \pm 0.18$ & $2.56 \pm 0.22$ \\
\hline TN (\%) & $0.22 \pm 0.06$ & $0.19 \pm 0.03$ & $0.08 \pm 0.02$ & $0.14 \pm 0.05$ & $0.17 \pm 0.03$ \\
\hline Canopy coverage (\%) & $83.6 \pm 13.7$ & $31.8 \pm 11.1$ & $44.5 \pm 9.5$ & $51.2 \pm 6.4$ & $61.8 \pm 12.3$ \\
\hline
\end{tabular}

Chl-a: chlorophyll- $a$; EC: electrical conductivity; HU: humidity; OM: organic matter; TC: total carbon; TN: total nitrogen. 
Table 3 The checklist of abundance of soil algae found in different farmlands in mid Taiwan

\begin{tabular}{|c|c|c|c|c|c|c|}
\hline Species & Figure & Rice paddy & Vegetable farm & Sugarcane farm & Tea garden & Orchard \\
\hline \multicolumn{7}{|l|}{ Cyanobacteria } \\
\hline Anabaena viguieri & $1 \mathrm{D}$ & C & - & - & - & - \\
\hline Anabaena sp. & & $\mathrm{R}$ & - & - & - & - \\
\hline Aphanothece stagnina & $1 \mathrm{~A}$ & $\mathrm{R}$ & $\mathrm{R}$ & - & - & - \\
\hline Gloeothece palea & $1 \mathrm{~B}$ & $\mathrm{R}$ & - & - & - & - \\
\hline Gloeocapsa sp. & & - & - & - & C & - \\
\hline Lyngbya major & $1 \mathrm{~F}$ & $\mathrm{R}$ & $\mathrm{R}$ & - & - & - \\
\hline L. putealis & $1 \mathrm{G}$ & $\mathrm{R}$ & - & - & - & - \\
\hline Lyngbya sp. & & $\mathrm{R}$ & $\mathrm{R}$ & - & - & $\mathrm{R}$ \\
\hline Microcystis sp. & & - & $\mathrm{R}$ & - & - & - \\
\hline Microcoleus paludosus & $1 \mathrm{H}$ & - & $\mathrm{R}$ & - & - & - \\
\hline M. subtorulosus & 11 & $\mathrm{R}$ & D & - & - & - \\
\hline Nostoc commune & $1 \mathrm{E}$ & C & - & - & - & - \\
\hline Nostoc sp. & & $\mathrm{R}$ & - & - & - & - \\
\hline Oscillatoria chlorina & $1 \mathrm{~J}$ & $\mathrm{R}$ & - & - & - & - \\
\hline O. curviceps & $1 \mathrm{~K}$ & $\mathrm{R}$ & - & - & - & $\mathrm{R}$ \\
\hline O. princeps & $1 \mathrm{~L}$ & - & $\mathrm{R}$ & - & - & - \\
\hline O. pseudogeminata & $1 \mathrm{M}$ & $\mathrm{R}$ & C & - & $\mathrm{R}$ & $\mathrm{R}$ \\
\hline O. tenuis & & $\mathrm{R}$ & $\mathrm{R}$ & - & $\mathrm{R}$ & $\mathrm{R}$ \\
\hline Oscillatoria sp. & & $\mathrm{R}$ & - & - & - & $\mathrm{R}$ \\
\hline Phormidium mucicola & $1 \mathrm{~N}$ & C & $\mathrm{R}$ & - & $\mathrm{R}$ & $\mathrm{R}$ \\
\hline Phormidium sp. & & $\mathrm{R}$ & $\mathrm{R}$ & - & - & $\mathrm{R}$ \\
\hline Synechococcus aeruginosus & $1 C$ & C & - & - & - & $\mathrm{R}$ \\
\hline \multicolumn{7}{|l|}{ Chlorophytes } \\
\hline Actinotaenium cucurbita & $2 \mathrm{G}$ & - & - & - & - & $\mathrm{R}$ \\
\hline Apiocystis sp. & & - & $\mathrm{R}$ & - & - & - \\
\hline Characium guttula & $2 \mathrm{~A}$ & - & - & - & - & $\mathrm{D}$ \\
\hline Chlamydomonas reinhardtii & $2 C$ & $\mathrm{R}$ & $\mathrm{R}$ & - & D & $\mathrm{R}$ \\
\hline Chlorella vulgaris & $2 \mathrm{E}$ & D & C & $\mathrm{R}$ & C & C \\
\hline Cladophora sp. & & $\mathrm{R}$ & C & C & C & C \\
\hline Closterium sp. & & $\mathrm{R}$ & - & - & - & - \\
\hline Cosmarium laeve & $2 \mathrm{H}$ & $\mathrm{R}$ & - & - & - & - \\
\hline C. quadrum & 21 & $\mathrm{R}$ & - & - & - & - \\
\hline C.regnellii & $2 \mathrm{~J}$ & - & - & $\mathrm{R}$ & $\mathrm{R}$ & - \\
\hline Klebsormidium flaccidum & $2 \mathrm{D}$ & $\mathrm{R}$ & C & $\mathrm{R}$ & $\mathrm{R}$ & $\mathrm{R}$ \\
\hline Scenedesmus quadricauda & $2 \mathrm{~B}$ & $\mathrm{R}$ & - & - & - & - \\
\hline Ulothrix variabilis & $2 \mathrm{~F}$ & - & D & C & $\mathrm{D}$ & $\mathrm{R}$ \\
\hline \multicolumn{7}{|l|}{ Diatoms } \\
\hline Achnanthes exigua & $4 \mathrm{~A}$ & $\mathrm{R}$ & - & - & - & - \\
\hline Amphora montana & $3 \mathrm{H}$ & - & - & $\mathrm{R}$ & $\mathrm{R}$ & C \\
\hline Encyonema leei & $3 F, 4 F$ & - & - & $\mathrm{R}$ & $\mathrm{R}$ & $\mathrm{R}$ \\
\hline Eunotia soleirolii & $3 G$ & - & - & - & $\mathrm{R}$ & - \\
\hline Hantzschia amphioxys & $3 \mathrm{~A}$ & $\mathrm{D}$ & C & $\mathrm{R}$ & $\mathrm{R}$ & C \\
\hline Navicula cryptocephala & $31,4 G$ & $\mathrm{R}$ & R & - & - & - \\
\hline
\end{tabular}


Table 3 The checklist of abundance of soil algae found in different farmlands in mid Taiwan (Continued)

\begin{tabular}{|c|c|c|c|c|c|c|}
\hline Na. gregaria & $3 \mathrm{~J}, 4 \mathrm{H}$ & C & $\mathrm{R}$ & - & - & - \\
\hline Na. mutica & $3 K, 4 I$ & - & - & - & - & $\mathrm{R}$ \\
\hline Na. pelliculosa & & $\mathrm{R}$ & $\mathrm{R}$ & - & - & - \\
\hline Na. rostellata & $3 \mathrm{~L}, 4 \mathrm{~J}$ & $\mathrm{R}$ & - & - & - & - \\
\hline Na. seminulum & $3 \mathrm{M}$ & - & - & - & - & D \\
\hline Na. subminuscula & $3 \mathrm{~N}, 4 \mathrm{~K}$ & $\mathrm{R}$ & - & - & - & $\mathrm{R}$ \\
\hline Navicula sp. & & R & $\mathrm{R}$ & - & - & $\mathrm{R}$ \\
\hline Nitzschia amphibia & $3 B$ & - & - & $\mathrm{D}$ & - & $\mathrm{R}$ \\
\hline Ni. amphibioides & $3 C$ & $\mathrm{R}$ & - & - & - & - \\
\hline Ni. levidensis & $3 \mathrm{D}, 4 \mathrm{~B}$ & C & - & - & - & - \\
\hline Ni. obtus & $4 C$ & $\mathrm{R}$ & $\mathrm{R}$ & - & - & $\mathrm{R}$ \\
\hline Ni. palea & $3 \mathrm{E}, 4 \mathrm{D}$ & R & $\mathrm{R}$ & $\mathrm{R}$ & $\mathrm{R}$ & $\mathrm{R}$ \\
\hline Ni. pusilla & $4 \mathrm{E}$ & - & - & - & - & $\mathrm{R}$ \\
\hline Pinnularia borealis & 30 & - & $\mathrm{R}$ & - & - & - \\
\hline P. gibba & $4 \mathrm{~L}$ & R & - & - & - & - \\
\hline P. intermedia & & - & $\mathrm{R}$ & - & - & - \\
\hline P. obscura & & $\mathrm{R}$ & - & - & - & $\mathrm{R}$ \\
\hline P. subcapitata & $3 P$ & - & $\mathrm{R}$ & R & $\mathrm{R}$ & - \\
\hline P. viridis & $3 Q$ & - & $\mathrm{R}$ & - & - & - \\
\hline Pinularia sp. & & - & $\mathrm{R}$ & - & $\mathrm{R}$ & - \\
\hline Surirella robusta & $4 \mathrm{M}$ & R & - & - & - & - \\
\hline \multicolumn{7}{|l|}{ Euglenoids } \\
\hline Euglena sp. & & R & - & - & - & - \\
\hline Lepocinclis ovum & & $\mathrm{R}$ & - & - & - & - \\
\hline
\end{tabular}

Abundance: D: Dominant (>20\%); C: Common (10-20\%); R: Rare $(<10 \%)$; -: Not found.

(Table 4). The dominant species in the rice paddies were Chlorella vulgaris and Hantzschia amphioxys, whereas those in the vegetable farms were $M$. subtorulosus and Ulothrix variabilis. The orchards were dominated by the green alga Charactium guttula and a diverse species of diatoms with a dominance of Na. seminulum. Relatively few species were found in the tea plantations, which were dominated by chlorophytes (such as Chlamydomonas reinhardtii and $U$. variabilis). The smallest number of species was found in the sugar cane farms, with only a few species of chlorophytes and diatoms inhabiting this habitat (Tables 3 and 4).

In studied farmlands, the community structure of soil algae varied significantly from type to type, with Shannon diversity index ranging between 1.89 and 4.63, evenness index between 0.54 and 0.93 , and Simpson's index between 0.44 and 0.91 (Table 5). The highest index values were measured for rice paddy, while the lowest for sugarcane farms. Noteworthy was that the indices in vegetable farms exhibited similar magnitude to that in orchards. The either types of lands also had more similar algal biomass (Chl- $a$ ) and number of species and genus (Table 4) than to other types.

\section{DNA sequencing for isolate identification}

Eight species of soil algae were successfully isolated and purified. The rDNA was extracted for sequencing and

Table 4 Summary of the total species (genus) numbers of soil algae revealed in various farmlands in mid Taiwan

\begin{tabular}{|c|c|c|c|c|c|}
\hline Group & Rice paddy & Vegetable farm & Sugarcane farm & Tea garden & Orchard \\
\hline Cyanobacteria & $18(9)$ & $11(6)$ & $0(0)$ & $4(3)$ & $8(4)$ \\
\hline Chlorophytes & $8(7)$ & $6(6)$ & $5(5)$ & $6(6)$ & $7(7)$ \\
\hline Diatoms & $15(6)$ & $12(4)$ & $6(5)$ & $7(6)$ & $12(6)$ \\
\hline Euglenoids & $2(2)$ & $0(0)$ & $0(0)$ & $0(0)$ & $0(0)$ \\
\hline Total & $43(24)$ & $29(16)$ & $11(10)$ & $17(15)$ & $27(17)$ \\
\hline
\end{tabular}



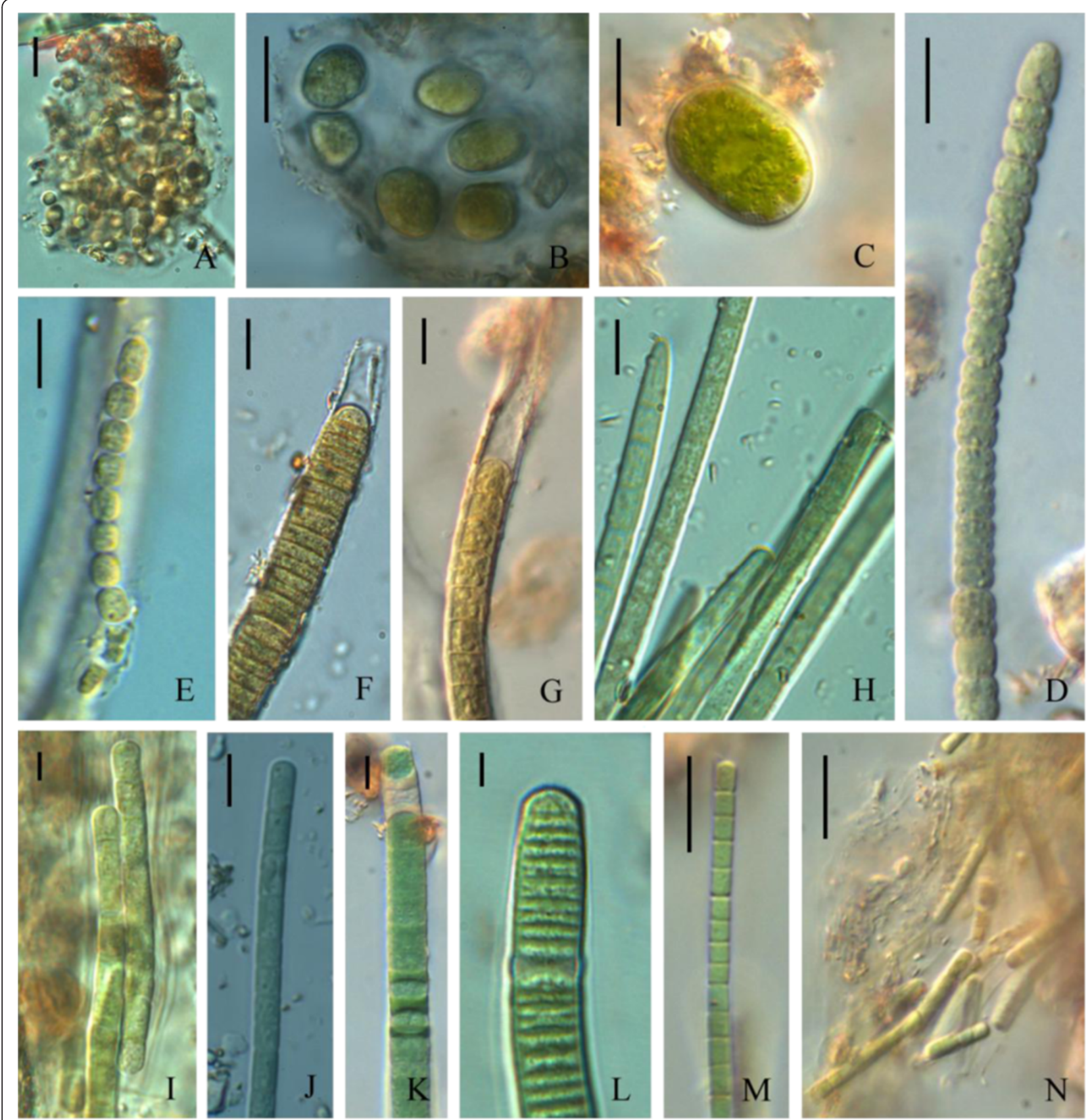

Figure 1 Soil cyanobacteria found at various farmlands in mid Taiwan. A: Aphanothece stagnina; B: Gloeothece palea; C: Synechococcus aeruginosus; D: Anabaena viguieri; E: Nostoc commune; F: Lyngbya major; G: L. putealis; H: Microcoleus paludosus; I: M. subtorulosus; J: Oscillatoria chlorina; K: O. curviceps; L: O. princeps; M: O. pseudogeminata; N: Phormidium mucicola. Bar $=10 \mu \mathrm{m}$.

assessed through BLAST for sequences comparable to those published in Genbank.

The closest relative taxon for the rDNA sequences of each isolate varied between $98 \%$ and $100 \%$ (Table 6). All of the sequence similarities of the isolated algae to species in Genbank were over the threshold values (i.e., 97.5\%) used to distinguish between species (Stackebrandt and Goebel, 1994).
Of the eight isolates studied, three were of cyanobacteria (M. paludosus, $N$. commune, and O. princeps), three of chlorophytes (Chla. reinhardtii, Chlo. vulgaris, and Klebsormidium flaccidum), and two of diatoms ( $\mathrm{Na}$. cryptocephala and Ni. palea) (Table 6). Morphologically, there were four filamentous species: M. paludosus, $N$. commune, O. princeps, and K. flaccidum. The other species were coccoid or long oval: Chla. reinhardtii, Chlo. 

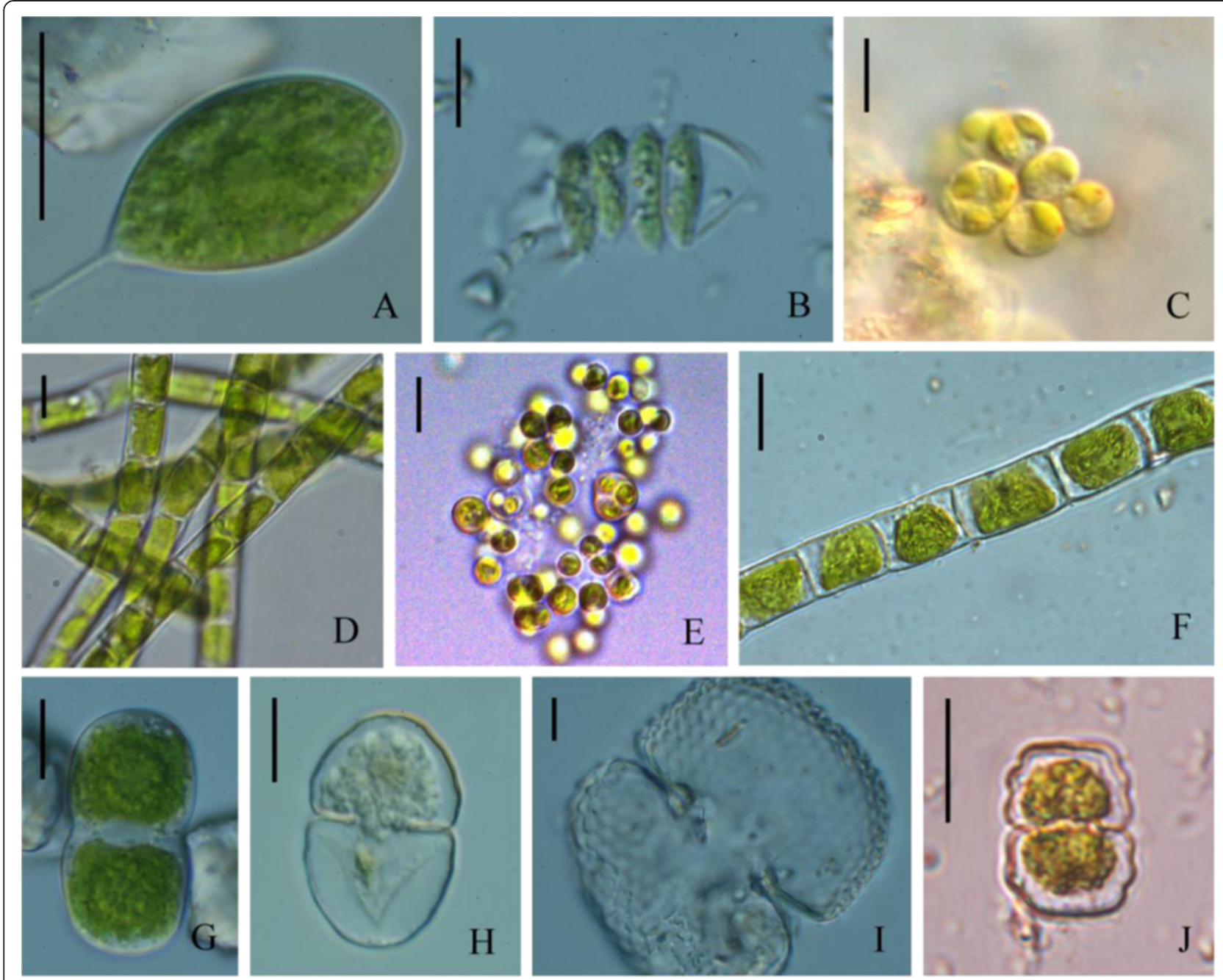

Figure 2 Soil green algae found at various farmlands in mid Taiwan. A: Characium guttula; B: Scenedesmus quadricauda; C: Chlamydomonas reinhardtii; D: Klebsormidium flaccidum; E: Chlorella vulgaris; F: Ulothrix variabilis; $\mathbf{G}$ : Actinotaenium cucurbita; H: Cosmarium laeve; I: Co. quadratum; J: Co. regnellii. Bar $=10 \mu \mathrm{m}$.

vulgaris, Na. cryptocephala, and Ni. palea. These eight consensus sequences were deposited in the NCBI database under the accession numbers JX661560 - JX661567.

\section{Discussion}

The nature of soil algal communities is the result of the complex influence of vegetation type, soil properties, and climatic conditions (Quesada et al., 1995, 1998). Our previous study indicated that water content (humidity) plays a very important role in the distribution and diversity of soil algae (Lin and Wu, 2013). This was also true in the present study, which is supported by significantly positive correlation between Chl- $a$ and humidity $(p<0.001$, cf. Table 2). Of the five types of farmland studied, rice paddies are kept wet or at a high humidity throughout the rice growth cycle, and the highest species diversity $(\mathrm{H}=4.63)$ was observed for this type of farmland (cf. Table 5). In contrast, sugar cane farms have a relatively dry soil environment compared with other types of farmland, and the lowest diversity $(\mathrm{H}=1.89)$ of soil alga was observed for this type.

The occurrence of soil algae in rice paddies varies with the growth stage of the rice (Roger and Reynaud, 1976). At the early growth stage, diatoms and unicellular green algae dominate. As the biomass of soil algae increases, there is a subsequent shift to dominance by filamentous green algae and non- $\mathrm{N}$-fixing cyanobacteria just before panicle initiation (Choudhary et al., 2007; Choudhary, 2009). This succession may be correlated with changes in the intensity of irradiation reaching the soil surface due to the altered canopy during the growth of the rice plant (Choudhary, 2009). Various fertilizers are also applied to rice paddies depending on the age of the rice plants, which influences the kind of nutrients available 

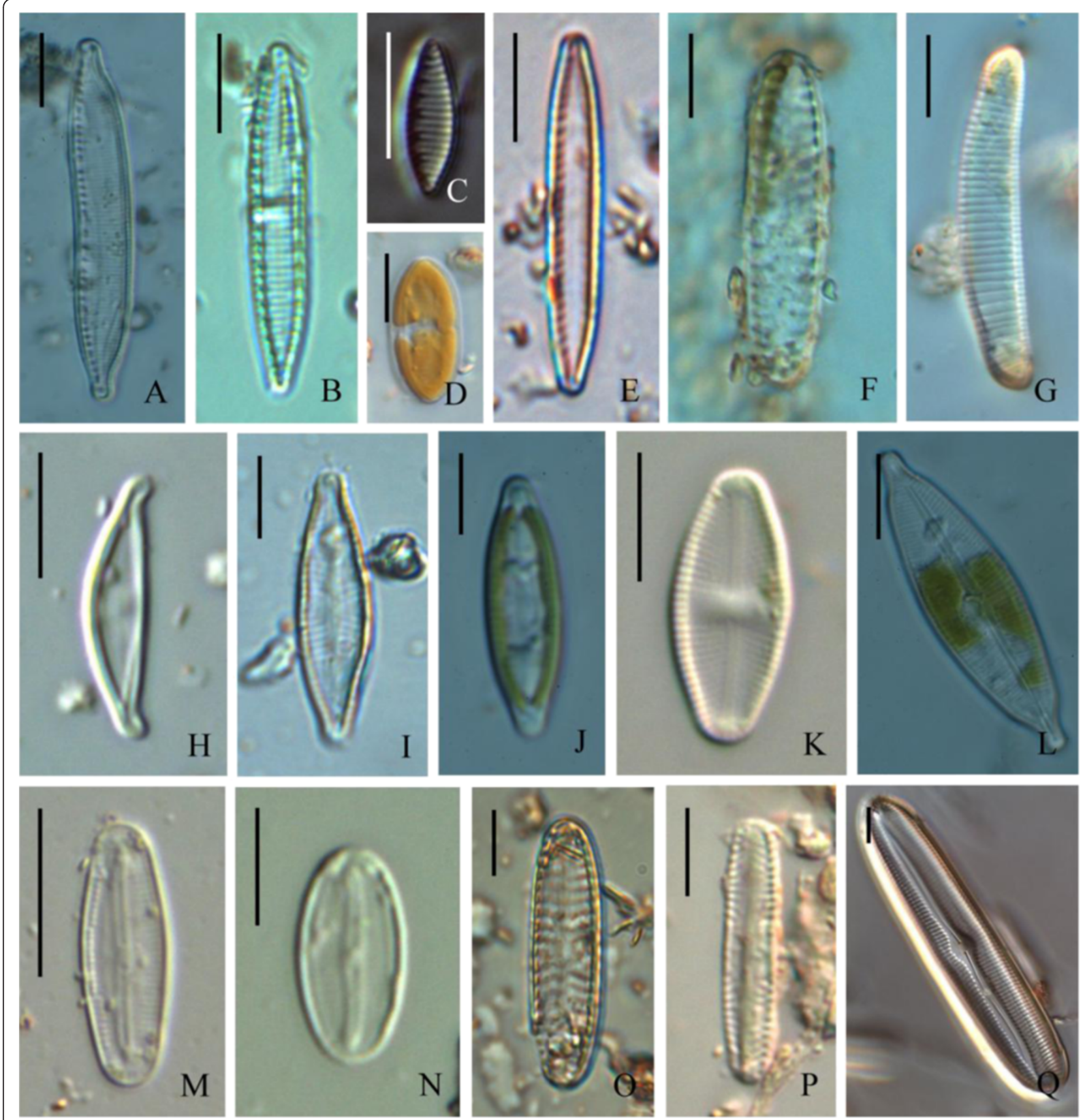

Figure 3 Soil diatoms found at various farmlands in mid Taiwan. A: Hantzschia amphioxys; B: Nitzschia amphibian; C: Ni. amphibioides; D: Ni. levidensis; E: Ni. palea; F: Encyonema leei; G: Eunotia soleirolii; H: Amphora montana; I: Navicula cryptocephala; J: Na. gregaria; K: Na. mutica; L: Na. rostellata; M: Na. seminulum; N: Na. subminuscula; O: Pinnularia borealis; P: P. subcapitata; Q: P. viridis. Bar $=10 \mu \mathrm{m}$.

for soil algae. Thus, changes in algal diversity in rice paddies are a result of the complex effects of irradiation, nutrients, and rice age. In this type of farm lands, nonheterocystous species of cyanobacteria might become dominant when fertilizers are applied and heterocystous strains are suppressed (Jutono, 1973). In the present study, some N-fixing species, including those of Anabaena, Gloeothece, Gloeocapsa, and Nostoc were found in the farmlands, together with higher amounts of the non$\mathrm{N}$-fixing species, such as Lyngbya, Microcystis, and Oscillatoria. Presumably, the occurrence of N-fixing species in rice paddy could be an indication of $\mathrm{N}$ deficiency, though there has had periodical application of fertilizers.

Farmlands are places of intensive anthropogenic activity, including tillage and the application of fertilizers, 

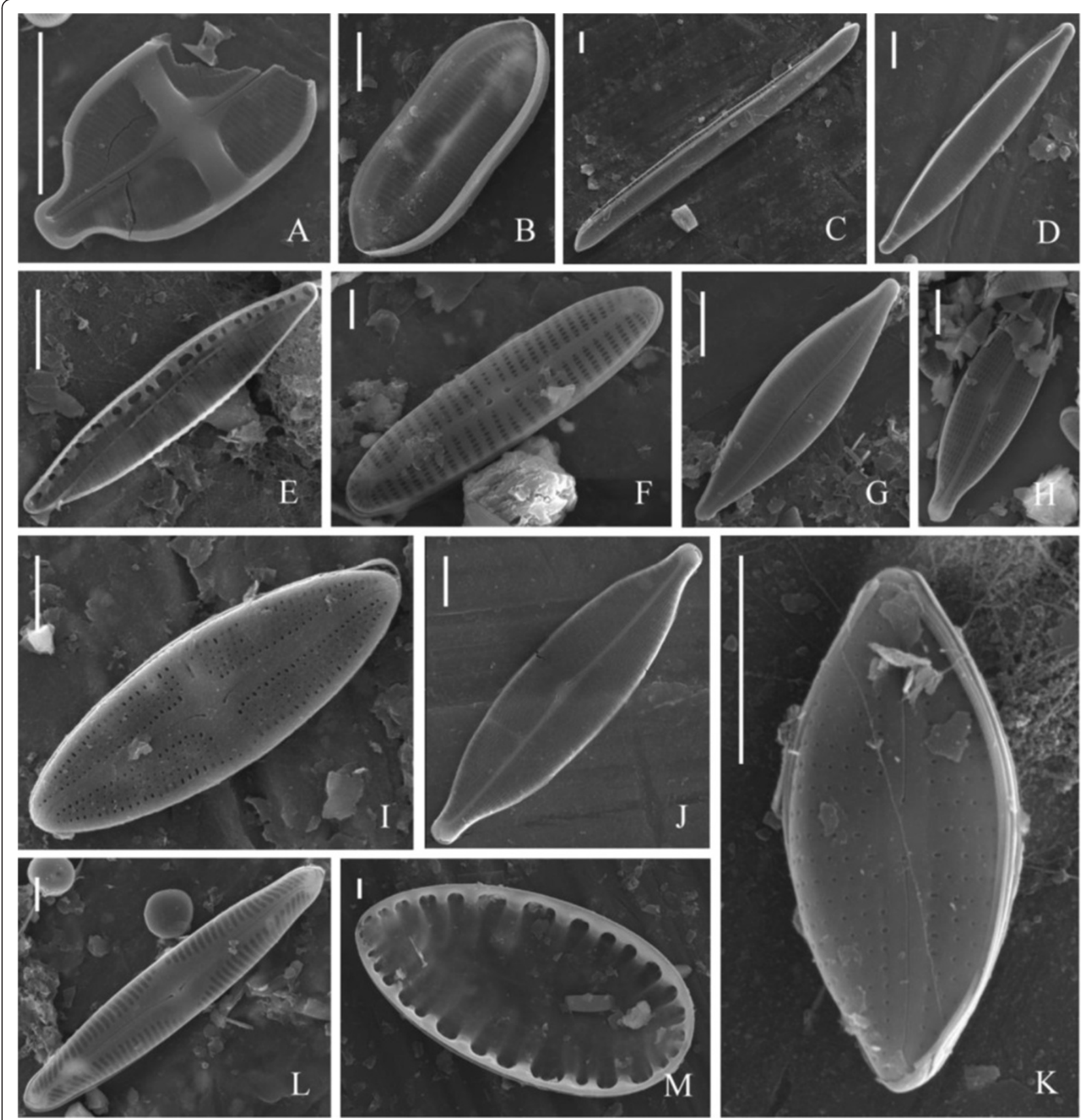

Figure 4 SEM photographs of soil diatoms found at various farmlands in mid Taiwan. A: Achnanthes exigua; B: Nitzschia levidensis;

C: Ni. obtusa; D: Ni. palea; E: Ni. pusilla; F: Encyonema leei; G: Navicula cryptocephala; H: Na. gregaria; I: Na. mutica; J: Na. rostellata; K: Na. subminuscula;

L: Pinnularia gibba; $\mathbf{M}$ : Surirella robusta. Bar $=5 \mu \mathrm{m}$.

Table 5 Diversity indices of soil algae revealed in various farmlands in mid Taiwan

\begin{tabular}{llllll}
\hline Index & Rice paddy & Vegetable farm & Sugarcane farm & Tea garden & Orchard \\
\hline Shannon diversity index & $4.63 \pm 0.46$ & $3.54 \pm 0.54$ & $1.89 \pm 0.22$ & $2.13 \pm 0.24$ & $3.49 \pm 0.60$ \\
Evenness index & $0.93 \pm 0.03$ & $0.88 \pm 0.05$ & $0.54 \pm 0.04$ & $0.72 \pm 0.03$ & $0.85 \pm 0.05$ \\
Simpson index & $0.91 \pm 0.03$ & $0.86 \pm 0.04$ & $0.44 \pm 0.05$ & $0.72 \pm 0.04$ & $0.84 \pm 0.03$ \\
\hline
\end{tabular}


Table 6 The isolated and rDNA-identified soil algae from the farmlands in mid Taiwan

\begin{tabular}{|c|c|c|c|c|}
\hline Species & Dimension $(\mu \mathrm{m})$ (width $\times$ length) & Accession number & Closest relative taxon & Similarity \\
\hline \multicolumn{5}{|l|}{ Cyanobacteria } \\
\hline Microcoleus paludosus & $5.3 \pm 1.2 \times 9.7 \pm 3.5$ & JX661567 & M. paludosus SAG 1449-1a (EF654090) & $98 \%$ \\
\hline Nostoc commune & $4.6 \pm 0.9 \times 5.3 \pm 0.7$ & JX661565 & N. commune CCAP 1453/24 (HE974995) & $99 \%$ \\
\hline Oscillatoria princeps & $5.7 \pm 2.4 \times 27.4 \pm 6.8$ & JX661566 & O. princeps (AF337649) & $98 \%$ \\
\hline \multicolumn{5}{|l|}{ Chlorophytes } \\
\hline Chlamydomonas reinhardtii & $9.4 \pm 3.2 \times 8.4 \pm 2.8$ & $J \times 661560$ & C. reinhardtii CC-503 (FJ436973) & $100 \%$ \\
\hline Chlorella vulgaris & $5.4 \pm 2.4 \times 5.1 \pm 2.2$ & JX661561 & C. variabilis (HQ914635) & $99 \%$ \\
\hline Klebsormidium flaccidum & $8.3 \pm 2.9 \times 17.5 \pm 6.1$ & JX661562 & K. flaccidum (DQ629183) & $100 \%$ \\
\hline \multicolumn{5}{|l|}{ Diatoms } \\
\hline Navicula cryptocephala & $6.5 \pm 0.7 \times 22.6 \pm 6.3$ & JX661563 & N. cryptocephala UTEX FD109 (HQ912603) & $99 \%$ \\
\hline Nitzschia palea & $3.7 \pm 1.2 \times 27.3 \pm 8.9$ & JX661564 & N. palea (DQ288289) & $99 \%$ \\
\hline
\end{tabular}

pesticides, and herbicides. Such activities affect the physico-chemical environment of soils and thus lower the diversity of soil algae. In the highly cultivated tea plantations, for example, a very low algal diversity $(\mathrm{H}=2.132$, cf. Table 5) was observed. Tea grows mainly on mountain slopes where soil is intensively worked and pesticides and herbicide are applied to keep the tea plants healthy and free of weeds. Such activities reduce the diversity (McCann and Cullimore, 1979; Megharaj et al., 1999; Mostafa and Helling, 2002) and development of characteristic soil algae (Kuzyakhmetov, 1998; Zancan et al., 2006). More importantly, the periodic application of a variety of fertilizers to enhance productivity results in the acidification of the soil environment (with a $\mathrm{pH}$ as low as 3.5-4.5, cf. Table 1). Therefore, it is why $\mathrm{pH}$ values were significantly negative correlated with TN (resulted from organic fertilizers) $(p<0.001)$ and Chl- $a$ $(p<0.05)$ (cf. Table 2). Apparently, the acidic environment is unfavorable for the development of biological crusts on the soil surface. Acidification is thus believed to be an important factor in lowering soil algal diversity.

The cyanobacterial species frequently occurred in the studied farmlands are of Anabaena, Calothrix, Lyngbya, Microcoleus, Nostoc, Oscillatoria, Phormidium, while green algae of Chlorella, Cladophora, Klebsormidium, and diatoms of Hantzschia, Navicula, Nitzschia, and Pinnularia. These species are cosmopolitan and widespread in various types of soils in literatures (Song et al., 2005; Begum et al., 2008; Khaybullina et al., 2010). In contrast, species of cyanobacteria such as Cylindrospermum, Pseudoanabaena, Scytonema, and Tricormus occurred only rarely. These species are known to be susceptible to pesticides, disturbance (such as tillage), and heavy metal pollution (Zancan et al. 2006), which are commonly applied in farmlands. It is possibly why they only rarely appeared in the farmlands studied.

Nitrogen is a limiting nutrient for crop growth in many farms. Fertilizers are commonly used in N-deficient farms
(Malik et al., 2001). Algal inoculation, or so-called algalization, has been applied as an alternative to fertilizer because it exerts a positive effect on soil properties (Aiyer et al., 1972) and provides better N-availability than chemical fertilizers (Tirol et al., 1983). Previous reports have shown that the use of cyanobacteria results in a better yield and improves the $\mathrm{N}$ content and nitrogenase activity in rice paddies through biological $\mathrm{N}$ fixation (Gurung and Prasad, 2005; Tripathi et al., 2008). In addition, it increases the aggregation of soil particles, the water-holding capacity, P-availability, and the quantity of microflora (Watanabe and Roger, 1984). Cyanobacterial biofertilizers are eco-friendly and cost effective for farmlands. In this regard, the $\mathrm{N}$-fixing species of cyanobacteria identified in this study are good candidates for biofertilizers in Taiwan.

The majority of soil organisms are also difficult to culture under laboratory conditions (Amann et al., 1995; Pace, 1997; Nübel et al., 2000). In this study, we only successfully isolated 8 isolates from 64 samples (ca. 12.5\%). The identification of soil algae is difficult, because of insufficient available morphological data or similar morphological characteristics for the microorganisms grown in

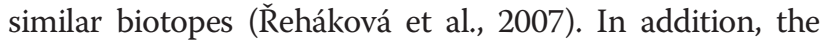
morphology of some algae might be altered under cultured conditions (Ward et al., 1992; Burja et al., 2001; Lin et al., 2012). Thus, we employ DNA sequence data in this study, as suggested by Dorador et al. (2008), in supplement to morphological characteristics. The DNA sequence data allow a comparison with already reported known species.

\section{Conclusions}

This article reported for the first time the diversity of soil algae in five types of farmland in mid-Taiwan, which were supported by the data from polyphasic approaches including cultivation, morphological studies, and rDNA sequences. Sixty-four taxa of cyanobacteria, diatoms, green algae, and euglenoids were identified. The highest species 
diversity was observed in the rice paddy, while the lowest in sugar cane farms. The humidity and acidity were the most important environmental factors determined the diversity of soil algae in the farmlands studied.

\section{Abbreviations}

CC: Canopy coverage; Chl-a: Chlorophyll-a; D: Simpson's diversity index; E: Evenness index; EC: Electrical conductivity; H: Shannon species diversity index; HU: Humidity; OM: Organic matter; TC: Total carbon; TN: Total nitrogen.

\section{Competing interests}

The authors declare that they have no competing interests.

\section{Authors' contributions}

Lin CS and Wu JT carried out the studies of the morphological and molecular characteristics of soil algae. Chou TL carried out the preparation and SEM observations. All authors read and approved the final manuscript.

\section{Received: 9 July 2013 Accepted: 16 September 2013}

Published: 27 September 2013

\section{References}

Aiyer RS, Salahudeen S, Venkataraman GS (1972) On a long term algalization field trials with high yielding rice varieties: Yield and Economics. Ind J Agric Sci 42:382

Amann Rl, Ludwig W, Schleifer KH (1995) Phylogenetic identification and in situ detection of individual microbial cells without cultivation. Microbiol Rev 59:143-169

Anagnostidis K, Komárek J (1990) Modern approaches to the classification of Cyanophyta, Stigonematales. Arch Hydrobiol 14:224-286

Ball DF (1964) Loss-on ignition as estimate of organic matter and organic carbon in non-calcareous soils. J Soil Sci 15:84-92

Begum ZNT, Mandal R, Amin FB (2008) Quantification and nitrogen fixation of cyanobacteria in rice field soils of Bangladesh. Bangladesh J Bot 37:183-188

Bérard A, Dorigo U, Humbert JF, Martin-Laurent F (2005) Microalgae community structure analysis based on 185 rDNA amplification from DNA extracted directly from soil as a potential soil bioindicator. Agronomie 25:1-7

Burja AM, Tamagnini P, Bustard MT, Wright PC (2001) Identification of the green alga, Chlorella vulgaris (SDC1) using cyanobacteria derived $16 \mathrm{~S}$ rDNA primers: targeting the chloroplast. FEMS Microbiol Lett 202:195-203

Chen SH, Wu JT (1999) Paleolimnological environment indicated by the diatom and pollen assemblages in an alpine lake of Taiwan. J Paleolimnol 22:149-158

Choudhary KK (2009) Occurrence of Chroococcaeae during rice cultivation in North Bihar, India. Bangladesh J Plant Taxon 16:57-63

Choudhary KK, Singh SS, Mishra AK (2007) Nitrogen fixing cyanobacteria and their potential applications. In: Gupta RK, Pandey VD (eds) Advances in Applied Phycology. Daya Publishing House, New Delhi, pp 142-154

Colwell RK (2009) Estimate S: statistical estimation of species richness and shared species from samples. Version 8.2. User's Guide and application published at: http://purl.oclc.org/estimates

Desikachary TV (1959) Cyanophyta. Indian Council of Agricultural Research, monographs on Algae, New Delhi, India

Dorador C, Vila I, Imhoff JF, Witzel KP (2008) Cyanobacterial diversity in Salar de Huasco, a high altitude saline wetland in northern Chile: an example of geographical dispersion? FEMS Microbiol. Ecol 64:419-432

Ernst A, Black T, Cai Y, Panoff JM, Tiwari DN, Wolk CP (1992) Synthesis of nitrogenase in mutants of the cyanobacterium Anabaena sp. PCC 7120 affected in heterocyst development. J Bacteriol 174:6025-6032

Evans RD, Johansen JR (1999) Microbiotic crusts and ecosystem processes. Crit Rev Plant Sci 18:183-225

Fujita Y, Ohtsuka T (2005) Diatoms from paddy fields in northern Laos. Diatom 21:71-89

Gurung S, Prasad BN (2005) Azolla and cyanobacteia (BGA): Potential biofertilizers for rice. Sci World 3:85-89

Hoffmann L (1989) Algae of terrestrial habitats. Bot Rev 55:77-105

Hu CX, Zhang DL, Liu YD (2004) Research progress on algae of the microbial crusts in arid and semiarid regions. Prog Nat Sci 14:289-295
Jackson ML (1962) Soil Chemical Analysis. Prentice-Hall, Inc., Englewood Cliffs, N. J., p 240

John DM, Whitton BW, Brook AJ (2002) The Freshwater Algal Flora of the British Isles. Cambridge University Press, Cambridge

Jutono (1973) Blue-green algae in rice soils of Jogiakarta, central Java. Soil Bid Biochem 5:91-95

Kannaiyan S (1990) Biotechnology of biofertilizer for rice. Tamil Nadu Agricultural University, Coimbatore, Tamil Nadu, India, 212

Khaybullina LS, Gaysina LA, Johansen JR, Krautová M (2010) Examination of the terrestrial algae of the Great Smoky Mountains National Park, USA. Fottea 10:201-215

Kobayasi H, Idei M, Mayama S, Nagumo T, Osada K (2006) H. Kobayasi's Atlas of Japanese Diatoms Based on Electron Microscopy. Uchida-rokakuho, Tokyo, Japan, in Japanese

Komárek J, Anagnostidis K (1999) Cyano-prokaryota, 1. Chroococcales. In: Ettl H, Gärtner G, Heynig H, Mollenhauer D (eds) Süßwasserflora von Mitteleuropa, 19/1st edn. Gustav Fischer Verlag, Stuttgart, New York, p 548

Komárek J, Anagnostidis K (2005) Cyano-prokaryota, 2. Oscillatoriales. In Büdel, B., Gärtner, L. Krienitz and M. Schlagerl (eds.). Süßwasserflora von Mitteleuropa, vol. 19/2. Elsevier GmbH, München, p 760

Kuhl A (1962) Zur Physiologie der Speicherung kondensierter anorganischer Phosphate in Chlorella. Vortr Gesamtgeb Bot NF 1:157-166

Kuzyakhmetov GG (1998) Productivity of algocenoses in zonal arable soils of steppe and forest-steppe. Eurasian Soil Sci 31:406-410

Lin CS, Wu JT (2013) Environmental factors affecting the diversity and abundance of soil photomicrobes in arid lands of subtropical Taiwan. Geomicrobiol J, doi:10.1080/01490451.2013.828135

Lin CS, Lin YH, Wu JT (2012) Biodiversity of the epiphyllous algae in a Chamaecyparis forest of northern Taiwan. Bot Stud 53:505-515

Malik FR, Ahmed S, Rizki YM (2001) Utilization of lignocellulosic waste for the preparation of nitrogenous biofertilizer. Pakistan J Biol Sci 4:1217-1220

Margalef R (1958) Information theory in ecology. Gen Syst 3:36-71

McCann AE, Cullimore DR (1979) Influence of pesticides on the soil algal flora. Residue Rev 72:1-32

Megharaj M, Singleton I, Kookana R, Naidu R (1999) Persistence and effects of fenamiphos on native algal populations and enzymatic activities in soil. Soil Biol Biochem 31:1549-1553

Metting B (1981) The systematics and ecology of soil algae. Bot Rev 47:195-312

Mishra U, Pabbi S (2004) Cyanobacteria: A potential biofertilizer for rice. Resonance 9:6-10

Mostafa FIY, Helling CS (2002) Impact of four pesticides on growth and metabolic activities of two photosynthetic algae. J Environ Sci Health B 37:417-444

Nübel U, García-Pichen F, Muyzer G (1997) PCR primers to amplify 16S rRNA genes from Cyanobacteria. Appl Environ Microbiol 63:3327-3332

Nübel U, García-Pichel F, Clavero E, Muyzer G (2000) Matching molecular diversity and ecophysiology of benthic canobacteria and diatoms in communities along a salinity gradient. Environ Microbiol 2:217-226

Pace NR (1997) A molecular view of microbial diversity and the biosphere. Science 276:734-740

Patrick R, Reimer CW (1975) The Diatoms of the United States, vol. 2. Monogr. Acad. Nat. Sci, Philadelphia, pp 1-21

Prescott GW (1962) Algae of the Western Great Lake Area. Brown Company Publ, W. M. C

Presting GG (2006) Identification of conserved regions in the plastid genome: implications for DNA barcoding and biological function. Can J Bot 84:1434-1443

Quesada A, Sánchez-Maeso E, Fernández-Valiente E (1995) Seasonal variation of chemical properties of rice field soil from Valencia. Spain CommunSoil Sci Plant Anal 26:1-19

Quesada A, Nieva M, Leganés F, Ucha A, Martín M, Prosperi C, Fernández-Valiente E (1998) Acclimation of Cyanophytal communities in rice fields and response of nitrogenase activity to light regime. Microbial Ecol 35:147-155

Rai LC, Tyagi B, Rai PK, Mallick N (1998) Inter-active effects of UV-B and heavy metal $(\mathrm{Cu}$ and $\mathrm{Pb})$ on nitrogen and phosphorus metabolism of a $\mathrm{N}_{2}$ fixing cyanobacterium Anabaena doliolum. Environ Exp Biol 39:221-223

Rai LC, Kumar HD, Mohn FH, Soeder CJ (2000) Services of algae to the environment. J Microbiol Biotechnol 10:119-136

Řeháková K, Johansen JR, Casamatta DA, Song LX, Vincent J (2007) Morphological and molecular characterization of selected desert soil cyanobacteria: three species new to science including Mojavia pulchra gen. et sp. nov. Phycologia 46:481-502 
Relwani LL (1963) Role of blue green algae on paddy field. Curr Sci 32:417-418 Roger P, Reynaud P (1976) Dynamics of the algal populations during a culture cycle in a Sahel rice field. Rev Ecol Biol Sol 13:545-560 (in French with English summary)

Roger PA, Reynaud PA (1982) Free-living blue-green algae in tropical soils. Martinus Nijhoff Publisher, La Hague

Saunders GW (1993) Gel purification of red algal genomic DNA: an inexpensive and rapid method for the isolation of polymerase chain reaction-friendly DNA. J Phycol 29:251-254

Shannon CE, Weaver W (1949) The mathematical theory of communications. University of Illinois Press, Urbana, III

Sherwood AR, Presting GG (2007) Universal primers amplify a 23S rDNA plastid marker in eukaryotic algae and cyanobacteria. J Phycol 43:605-608

Simpson EH (1949) Measurement of diversity. Nature 163:688

Song T, Martensson L, Eriksson T, Zheng W, Rasmessen U (2005) Biodiversity and seasonal variation of the cyanobacterial assemblage in rice paddy field in Fujian, China. FEMS Microbiol Ecol 54:131-140

Srivastava AK, Ara A, Bhargava P, Mishra Y, Rai SP, Rai LC (2007) A rapid and costeffective method of genomic DNA isolation from cyanobacterial culture, mat and soil suitable for genomic fingerprinting and community analysis. J Appl Phycol 19:373-382

Stackebrandt E, Goebel BM (1994) Taxonomic note: a place for DNA-DNA reassociation and $16 \mathrm{~S}$ rRNA sequence analysis in the present species definition in bacteriology. Int J Syst Bacteriol 44:846-849

Stanier RY, Kunisawa R, Mandel M, Cohen-Bazire G (1971) Purification and properties of multi-cellular blue-green algae (order Chlorococcales). Bacteriol Rev 35:171-205

Tirol A, Roger PA, Watanabe I (1983) Fate of nitrogen from a blue-green alga in a flooded rice soil. Soil Sci Plant Nutri 29:1-8

Tripathi RD, Dwivedi S, Shukla MK, Mishra S, Srivastava S, Singh R (2008) Role of blue green algae biofertilizer in ameliorating the nitrogen demand and flyash stress to the growth and yield of rice (Oryza sativa L.) plants. Chemosphere 70:1919-1928

Tsujimura S, Nakahara H, Ishida H (2000) Estimation of soil algal biomass in salinized irrigation land: a comparison of culture dilution and chlorophyll $a$ extraction methods. J Appl Phycol 12:1-8

Ward DM, Bateson MM, Weller R, Ruff-Roberts AL (1992) Ribosomal rRNA analysis of microorganisms as they occur in Nature. Adv Microbiol Ecol 12:219-286

Watanabe I, Roger PA (1984) Nitrogen fixation in wetland rice field. In: Subba Rao NS (ed) Current Developments in Biological Nitrogen Fixation. Co. Oxford and IBH, New Delhi, Bombay, Calcutta, pp 237-276

Whitton AB, Potts M (2000) The Ecology of Cyanophyta. Kluwer Academic Publishers, Dordrecht, pp 233-255

Wilson LT (2006) Cyanobacteria: A Potential Nitrogen Source in Rice Fields. Texas Rice 6:9-10

Yanni YG (1992) The effect of cyanobacteria and Azolla on the performance of rice under different levels of fertilizer nitrogen. World J Microbiol Biotechnol 8:132-136

Zancan S, Trevisan R, Paoletti MG (2006) Soil algae composition under different agro-ecosystems in North-Eastern Italy. Agricult Ecosyst Environ 112:1-12

Zenova GM, Shtina EA, Dedysh SN, Glagoleva OB, Likhacheva AA, Gracheva TA (1995) Ecological relations of algae in biocenoses. Mikrobiologiya 64:121-133

doi:10.1186/1999-3110-54-41

Cite this article as: Lin et al:: Biodiversity of soil algae in the farmlands of mid-Taiwan. Botanical Studies 2013 54:41

\section{Submit your manuscript to a SpringerOpen ${ }^{\circ}$ journal and benefit from:}

- Convenient online submission

- Rigorous peer review

- Immediate publication on acceptance

- Open access: articles freely available online

- High visibility within the field

- Retaining the copyright to your article

Submit your next manuscript at $>$ springeropen.com 